\title{
PANRITA LOPI: \\ Cultural Value and Religiosity Behind Professionalism of Making Pinisi Boats in Bulukumba
}

\author{
${ }^{1}$ Eymal B. Demmallino, ${ }^{2}$ Tamzil Ibrahim, ${ }^{3}$ Yopie Lumoindong \\ 1,2,3 Department of Socio-Economic, Faculty of Agriculture, Hasanuddin University \\ Email Coresponden: demmallino1964@yahoo.com
}

\begin{tabular}{l}
\hline ARTICLE INFO \\
\hline Keywords: \\
Panrita lopi; Cultural \\
Value; Religiosity; Pinisi \\
Boats. \\
\\
How to cite: \\
Demmallino, E.B., \\
Ibrahim, T., Lumoindong, \\
Y. (2019). Panrita Lopi: \\
Cultural Value and \\
Religiosity Behind \\
Professionalism of Making \\
Pinisi Boats in Bulukumba \\
Regency. ETNOSIA: \\
Jurnal Etnografi \\
Indonesia. 4(1): 1 - 19. \\
DOI: \\
10.31947/etnosia.v4i1.6422
\end{tabular}

\begin{abstract}
The main of this article to be expressed are Cultural Values and the Religiosity Behind the Skills (Kepanritaan) of Pinisi Boat Making in a very well-known community of boat makers in Ara, Bira and Tanalemo Villages, Bontobahari District, Bulukumba Regency, South Sulawesi. This research uses the verstehen method (Weber in Ritzer and Goodman, 2004 and Kaelan, 2005) on Pinisi Boat Making Activities and Changes from the beginning to the era of shipping modernization. The data was collected by combining comprehensive data collection techniques (observation, in-depth interviews, documentation, and triangulation: Sugiyono, 2007) and analyzed using interpretive post positivistic qualitative descriptive analysis method (with systemic complementary analysis procedures: Data Collection), Grouping, Categorization, and Discarding Insignificant Data (Data Reduction), Mapping Data on Causality between Data Categorization, and Conclusion: Miles and Huberman, 1995). The results of the research show that the professionalism in making pinisi boats is built on the basis of assessment with the underlying occult values. A cultural value that tends to be ecologically oriented in the sense of keeping the relationship harmonious with the natural ruler in a magical way. These values tend to weaken amid the development of shipping modernization and the development of the boat-making industry.
\end{abstract}

Copyright @ 2019 ETNOSIA. All rights reserved.

\section{Introduction}

Bulukumba Regency is known as Butta Panrita Lopi (boat expert area): Boat Expert Palace. The place where Pinisi boats are made and delivered using local knowledge handed down from generation to generation since several centuries ago. Butta Panrita Lopi (boat expert area) actually has the meaning of an expert 
in making boats and experts in shipping boats. The boatbuilder is in the hands of the Ara Community who are domiciled in Ara Village and Lemo-Lemo Community, which are now mostly domiciled in Tana Beru Village (formerly in Lemo-Lemo Village). Being experts in shipping boats is in the hands of the Ulung Tanjung Bira Sailor Community which is now domiciled in Bira Village (now the village is blooming into Bira Village and Darubiah Village). The villages are located in the Bontobahari District of Bulukumba Regency. Since the beginning of the discovery of the boat in Bulukumba Regency, the three communities respected each other's expertise and the mutual respect was mentioned in the Sinrilik Datu Museng a few centuries ago:

"Panre patangara'na Bira, Pasinggokolo tu Arayya, Pabingkung tu Lemo Lemoyya"
Meaning: The Bira community is respected in terms of designing and
determining the quality of the boat because it is they who use or pay for it,
hence it is known as the Great Seaman. The Ara community is respected in
terms of making boats, especially large boat boats (pinisi and wooden boats),
and the Lemo-Lemo Community is respected in refining boats and therefore
they tend to make boats of smaller sizes than the boats made by the Ara
Community.

Umar Kayam in his work "Sawerigading and Tiga Desa Pinisi" revealed that those who lived in the three villages (Ara, Bira, and Lemo-Lemo: before area expantion) had indeed been ordered and contracted by South Sulawesi cultural heroes, Saweriganding to become pinisi conservationists, and not in other villages in South Sulawesi. Those who lived in the three neighboring villages that have been posted have been appointed by Saweriganding to become an established Trio (TRIUMP) in pinisi conservation (Saenong, 2013: 14).

This research holds that in the era of modernization, cultural values and religiosity that guided expertise in making pinisi boats have also undergone changes. The People's Shipyard which produces boats is no longer in the size of the tonnage as before (100-150 tons), but has experienced a continuous increase in market demand (modern market) and until now the weight of the boat (tonnage) ordered by buyers (especially from abroad) has reached between 1,500 - 2,000 tons and this shows that a capitalization process has taken place there. The manufacturing process has also used modern electronic carpentry tools which show that people's shipyards are characterized by industrialization.

Structurally, these developments have also shown changes. If previously the boatbuilding experts in making boats deal directly with boat owners (SailorUser), now it has been brokered by "boat sellers" which can be called a capitalist who funds boat building or is in direct contact with potential boat buyers (especially from abroad: New User). This capitalist employs a group of expert boat makers consisting of 10-15 people. In addition to the duty of the capitalist 
to promote or look for boat buyers also at the same time looking for raw materials (wood) in various places (generally in Southeast Sulawesi) and then constructed by a group of expert boat makers. Such structural changes in Durkheim's view are called structural differentiation which then gives birth to contractual bonds between boat buyers and boat sellers and between boat sellers and boat maker groups. This change in the view of Durkheim (in Ritzer, 2012) calls for a change in solidarity from mechanical solidarity to organic solidarity. The change in solidarity will ultimately change the work culture of the model or the amount of capacity (tonnage) of pinisi boats that are desired by the user which in addition is getting bigger and bigger is increasingly relying on engine power as its main driver.

As a result, it demands a better quality of wood raw materials, better quality of work, and respect for better quality. These changes can actually be seen as demands for modernization that must be adapted by boat builders and therefore require that they use carpentry equipment that must also be more modern. This demand will clearly shift old values that are more ecological to new values that are more economic in nature or in Weberian's view (in Ritzer, 2004) to change the rationality of value rationality that is more supernatural to the rationality of a more economic goal. The demand for such shifts in the empirical world is seen as the Colonization of the World of Life, an unfinished project that demands to be rationalized again towards real modernization (Ramos, 1980) or what is called Rationalization of the World of Life (Habermas, 1987 in Ritzer, 2012).

Based on the background above, the purpose of this article can be stated as follows: (1) Reveal the cultural values and religiosity that characterize the making of pinisi boats in Bulukumba Regency, (2) Analyzing whether cultural values and religiosity will remain in the midst of shipping modernization and the development of boat-making industries.

\section{Research Methods}

This research epistemology uses a post-positivistic approach to the tradition of phenomenology (Creswell, 1998). The choice of phenomenology epistemology is very appropriate in the effort to disclose Cultural Values and Religiosity Behind the Expertise (Professionalism) of Pinisi Boat Making in Bulukumba Regency and its changes in the era of shipping or public transportation as well as its influence on work ethics, work culture, and system of criticism in manufacturing organizations pinisi boat. Weber calls this epistemology phenomenology with terms in German: Verstehen (in Ritzer and Goodman, 2004 and Kaelan, 2005) or what is popularly called a term in the Indonesian Sociology Dictionary is understanding or also commonly called the Descriptive- 
Qualitative-Interpretative approach. The research location purposively selected Bira Village from three villages known as TRIO MAPAN, namely Bira Village, Ara Village, and Tanah Lemo Village (Tanah Beru Village) Bontobahari District, Bulukumba Regency or precisely where there are community shipyards that are making pinisi boats.

Based on the post-positivistic approach, this research fully uses qualitative research methods, so the research instruments will be very dependent on the researchers or the research team themselves (human instruments). As a human instrument, the researcher (research team) must be able to: (1) conduct a selfevaluation of: methodological understanding, mastery of theory and insight into the field under research, and its readiness to enter objects (both academically and logistically), and (2) function: determine the focus of research, choose key informants as valid data sources, conduct data collection, assess data quality, analyze data, interpret data, and make conclusions on its findings.

The types and sources of research data are: Primary data types in the form of: (1) Cultural Value and Religious Value Behind the Poetry of Pinisi Boatbuilding, (2) Development or Modernization of Pinisi Boats, (3) Effects of Shipping Modernization on Work Ethics, Work Culture, Systems The Poetry and Pinisi Boat Making Organization. The entire data is sourced directly from the Panrita Lopi; and Types of secondary data in the form of statistical data on the development of the number of boats, the number of shipyards, the number of boatbuilders, and data from previous research both from BPS Statistics, Industry and Trade, and at the local Regional Library.

The data collection technique is done comprehensively, starting from observation, in-depth interviews, documentation, and triangulation. Observations were made on the overall activity of making pinisi boats. In-depth interviews were specifically conducted with a number of key informants on the cultural values and religiosity behind the expertise in making pinisi boats, modernizing people's shipping, and their influence on values, work ethic, the system of crime, and boat-making organizations (people's shipbuilding industry). Documentation is carried out in addition to the shooting of pinisi boat-making activities, as well as the results of previous studies that are deemed relevant. Specific triangulation is carried out in three forms: tringulation (cross check) data sources, tringulation of data collection techniques, and triangulation of results from the overall results of using the overall data collection techniques (observation, interviews, and documentation). Furthermore, the data is analyzed by referring to the Qualitative Research Analysis Model (Miles and Hubaerman, 1992 and Sugiyono, 2007), which is carried out in four stages. The first stage, by collecting data (Data Collection). At this stage the data relating to the research objectives will be 
collected as much as possible from various sources. The second stage, by reducing data (Data Reduction). At this stage the collected data is sorted on the basis of data interests, then categorization is carried out, and selecting or removing non-essential ones. The third stage, by presenting data into a pattern (Data Display). At this stage the data that has been grouped based on the results of categorization in the second stage, mapped the relationship with each other. The fourth stage, is to draw conclusions on all findings during the research took place or can also be called concluding patterns into the form of hypotheses or grounded theories. Followed by testing the validity of the data (credibility - Legality, Reliability) Procedural and Comfirmability Objectivity. (Sugiyono, 2007).

\section{Results and Discussion}

\section{- Kepanritaan (Expertise) in Boat Making (Local Knowlegde)}

The success of the Nusantara Pinisi Boat in navigating the ocean to Voncouver Canada by performing at the 1986 expo and the Ammana Gappa Pinisi Boat arrived in Madagascar in 1991, and several subsequent shipping missions proved the greatness and strength of the pinisi boat construction. The greatness of a pinisi boat is actually a manifestation of the kepanritaan (expertise) of a sailor who controls a pinisi boat, while the construction strength of a pinisi boat is actually a manifestation of the cruelty of the boat makers.

Pinisi boats are the largest works of the Bugis Makassar boats and Indonesian created in the 1990s. Pinisi boat is actually the culmination of the culture of the the Bugis Makassar boats people. Initially the Bugis Makassar boats boat only one screen (Tanja Screen), then developed into three screens (Lambo Screen) and then developed to reach its peak with seven screens (Pinisi Screen). Even in the modernization era, which is precisely after the 1990s, along with the development or increase in tonnage of pinisi boat bodies, in addition to the pinisi screen it has also been equipped with engines as Motorboat Sailboats (consisting of Pinisi Sailboats and Lambo Motor Sailboats) and the latest development into a Motor Ship with a screen only as a symbol with the aim of reducing the tax burden from the government. Tanja Sailboats, Lambo Sailboats, and Pinisi Sailboats are categorized as traditional Bugis Makassar boats, while Motorcycle Sailboats and Motorboats are categorized as Modern Bugis Boats Makassar.

It is called a traditional boat because in its manufacture it uses simple carpentry tools, such as axes, machetes, saws (large and small), hoe, chisels, wooden hammers (large and small), vise, drill, bassi, singkolo, etc. which are still in total relying on human power in using the intended tools of carpentry tools and 
relying on wind power in the delivery of the craft from the use of the traditional carpentry tools. Furthermore, it is called modern because in addition to the boat tonnage, it is getting bigger and no longer relying on wind power as the main driving source or in other words relying on the engine as the main driver also in making it generally rely on electricity (electricity or fuel), such as: electric drill, chainsaw machine, electric ketam, vise, and takal. The last two are still classified as traditional carpentry tools. The use of electricity/fuel is recognized by boat makers can save time or can speed up work.

Regarding the expertise (local knowlegde) in boat building, boat experts agree that "the strength and size of the boat rests on the size of the keel beam and the construction of the boat wall". The longer keel (Lunas/kalabiseang), the bigger the boat. The keel beams are generally made of three or two pieces of wood which are quite large and are quite old or come from hard wood, such as iron wood or the like. Likewise, wood used as a boat wall is also used with wood that is quite old or comes from hardwood. The age of aging and violence from keel wood and wood walls is intended because the two parts come in direct contact with water and by anticipating the possibility of collisions with rocks. Herein lies the difference between a traditional boat and a modern boat (made from iron or iron plate), where the traditional boat's strength lies in the keel strength and the wall of the boat on a modern ship whose strength lies in the strength of the frame. In making traditional boats, the skeleton of the boat adjusts to the construction of the boat body or only acts as a supporting reinforcement of the keel strength and the wall of the boat.

At first the boat makers in constructing the boat did not use a definite tool or size, such as meters, but used the size: soles of the feet, inch, cubits and feet or sizes that were on the leader's body. Now, besides still using traditional sizes, it has also been used as a meter. Nevertheless, overall from the construction of the boat it still uses knowledge (estimation) on the basis of the experience of the punggawa (leader of boat makers) which accumulates from year to year or from generation to generation from their ancestors. This science is more precisely called estimation. If the boat is to be made bigger, then the keel beam is sufficiently long enough and the construction of the boat body is made fatter like the construction of the body of a lambo boat or a modern ship. Construction of a boat body like this is generally made wider so that it looks more floating above sea level than traditional boats. In traditional boats the boat's body looks more submerged above sea level because its main driver is wind, which is not only from the back of the boat but generally comes from the side (left and right) of the boat and not even from the boat's bow, is also because the boat pole is quite high which is equipped with a screen that is wide enough so that if there are not many parts of the boat that sink, it is possible to reverse it. That is why if a traditional boat does not have a cargo, the boat body is filled with stone 
balans (tula'bara). In addition to normalizing the way the boat is used a pair of side rudders (bolsters) and three sheets of front screen (cocoro). The side steering serves to control the back of the boat so that it stays in position, as well as the front screen is also intended to control the front of the boat so that it remains in its position to move towards the desired direction. The latter is actually a part of the cruelty in shipping a boat.

\section{- Cultural Pattern in Boat Building}

Pinisi Boat is the culmination of culture for the Bugis tribe of Makassar especially from the Konjo Community. As a culture, the making of pinisi boats has never been separated from the traditions carried out from generation to generation from their ancestors to the latest generation. Broadly speaking, there are three types of cultural traditions in making pinisi boats. The three features of the cultural tradition are as follows:

1) The Tradition of Cutting Down Keel Tree (Lunas) (Anna'bang Kalabiseang)

Keel (Kalabiseang) is the most basic component of a boat. Keel wood is prepared in advance through picking or felling selected trees from within the forest. In the view of the boat maker, keel wood may not originate from used wood, fallen trees, drifted wood, and/or defective wood. The keel wood must really come from intact and best wood trees in the forest area where trees are harvested or felled.

If the boat maker has found the selected tree in the forest area, then the leader concerned chooses "goodday" (according to the tradition of the Bugis Makassar) to start the logging ceremony. Selection of a good day like this also applies to every celebration in the social life of Bugis Makassar culture, such as at the beginning of the ceremony of wedding parties, starting a business, building a house, etc. If a good day has been established, the mustard prepares the equipment or equipment needed in the ceremonies to cut down the keel tree.

Every felling of a keel tree is carried out in the form of a ceremony as a sign of a request for permission from the "forest guard". In the perspective of the leader, every place in the world is guarded or controlled by supernatural beings, as is true in the real world, both on land and at sea. Each guard is seen as a leader or ruler in charge of a number of members assigned to guard certain parts of each smaller place on the earth, for example: patanna pa'rasangan (village guard), patanna biring kassi (guardian of coastal areas), patanna tamparang (sea territory guard), patanna borong (forest area guard), etc. Therefore, every time there is a celebration to do in that area, they must 
ask for permission in the hope that their efforts will not get a hitch or bring disaster to the leaders concerned. Requests for permission which are generally carried out in ceremonial form are actually manifestations of the view of the relationship between the macrocosm and the microcosm, where nature is always seen as a macrocosm and humans are seen as a microcosm. Humans are part of the macrocosm (nature), therefore humans must control themselves so as not to damage nature. The self-control effort in the view of pongawa mustard is done in the form of attitudes and behavior. Attitudes are generally shown through ceremonies and behavior is generally shown through procedures such as procedures for felling trees.

If a good day is set and equipment has been prepared, logging activities begin. Logging is led directly by leader, beginning with leaning an ax on the tree trunk to be cut down and putting other equipment around it. After the felling equipment has been placed, the leader surrounds the tree while reading a mantra/prayer 3 (three) times. If as long as the leader surrounds the tree there is equipment that moves especially the ax, then it is a sign that the ruler of the forest or tree has not given permission and for him it is necessary to provide offerings (suspicious canes) first and that also means that logging activities are temporarily delayed.

If the permit has been obtained from the ruler of the forest (tree), logging is done in a manner. First, the leader uses clean clothes, wears a black skull cap and sarong as a sign of respect for the ruler of the forest (macrocosm). Second, felling of trees is done before midday or when the sun is rising (moving upwards) with the hope (meaning) that boat income continues to increase. Third, in cutting down trees, the leader may not turn his back on the sun with the hope that the leader does not obstruct the boat's income. Fourth, the leader in starting tree felling activities must put his ax upward in the hope that the boat will have a good fortune. Fifth, in the felling of trees it is sought that the felled trees do not get caught in the surrounding trees in the hope that the boat will not be blocked. Sixth, the direction of the fall of the felled tree is directed towards the location of the boat making (bantilang) with the intention of creating a relationship between the boatmaking place and the place for keel wood (forest area) or in other words the boat provision continues or continues.

After the leader surrounds the tree and has obtained a permit marked with no moving equipment or logging equipment, the Leader takes a position around the tree facing the sun, then catches his breath and concentrates for a moment while communicating with the forest rulers (nature-macrocosm) with wondered: "Are you willing to cut down for your boat?" After the 
occult communication has been done or after the permission sign has been obtained, the leader reads the mantra/prayer as follows

"Pattimbonako buttayya. Katuhonako bosiya. Batelamunnako lukmanulhakim. Allah Taala antabbangko." Meaning: You are grown by soil. Maintained by rain. Planted by Lukmanulhakim. God Almighty cut you down.

After the mantra/prayer is read, followed by reading the Basmalah, and continues by saying in the heart: a ... i ... u while holding your breath and after that the leader starts to place his ax on the tree facing up as much as 3 times, then handed to one of the mustard to continue felling trees until it's finished. If the tree has been cut down, the Leader takes over the work by measuring the tree trunk with a Leader foot gauge. Performed by walking with the soles of the feet continued from one end of the tree stem to the end of the next tree trunk If the size of the Leader's foot reaches 11 continuous strokes, the boat tonnage amount is $3 \times 11=33$ : which means the boat tonnage can reach between $30-40$ tons. This measurement is carried out to determine how much the required keel length is according to the weight of the boat tonnage ordered by the boat owner. Excess of the required keel length is cut or discarded. From here punggawa views that: 'Anulebba' is indeed a borong ri borong nani patonrang ri bantilang": meaning: the boat has been completed in a new forest and then built in a boat building. In the assessment under the mastery of the Leader: the size of the tonnage (weightcapacity) of the boat is very much determined by the length of the short paid. Thus, if the keel length has been determined, all timber needs in boat building are known or at least predictable.

\section{2) Tradition of Cutting off Keel (Annatta' Kalabiseang)}

If the tradition of anna'bang kalabiseang is a sign of the commencement of work in the forest area, the tradition of annatta 'kalabiseang is a sign of the commencement of work at the boat building shipyard (bantilang). Annatta 'implies cutting off the keel end part (kalabiseang) to be leveled and then connected with a piece of wood which is built a little standing on the front and back of the boat (sotting). This connection effort is seen as an effort to bring together the mother and father who will later give birth or create a boat (child). Because of that in the view of the Leader of the boat maker, the boat is actually a living creature (human) born of marriage between the mother (kalabiseang) and father (sotting).

The connection between kalabiseang (mother) and sotting (father) is seen as the forerunner to the creation of a (human) fetus because of that connection is made sacred as a sacred wedding ceremony. At first the blocks made by Kalabiseang amounted to three sticks and then joined to each other where 
each connection was always seen as an effort to bring together the mother and father, but because a tall tree or long beam had been found, generally only one beam was made. The reduction in the number of beams is actually contrary to the magical view of the Leader, where if the kalabiseang beam consists of three plus front sotting and back sotting, the number of beams is 5 and this number is seen in accordance with the Pillars of Islam, but actually if the block consists of only one the beam is then technically much stronger. Here there are differences between magical views and technical views. For the Leader of the boat maker, the strength of the boat is very much determined by its compatibility with the magical view.

Just as in the tradition of anna'bang kalabiseang starting with first determining the day in accordance with the Bugis Makassar perspective, then in the tradition of anniversaries, he said, it was also preceded by the determination of good days and agreed upon by boat owners and Leader of boat makers. On the appointed day, the Leader placed Kalabiseang in the middle of Bantilang (which had been prepared in advance) with two pieces of blocks measuring approximately one meter in diameter. The base part extends to the sea and is placed slightly higher than the other end with the intention that the boat to be built does not have a declining fate (tattuasa). Before the ceremony begins, the boat owner prepares completeness including: two meters of white cloth, a pair of mature chickens, diamonds, sweet bananas, brown sugar, coconut, and several kinds of traditional cakes and censer. The mustard Leaders prepare boat equipment that will be used in the annatta activities, he said, such as chisels, hammers, saws, drills, etc.

Shortly before the Annatta ceremony procession, when it began, Punggawa (the local name Panrita Biseang or expert boat maker) took a squat position at the far right if the east side faced the boat owner who was left from the sea. The boat makers were present and stood behind the leader, as well as the captain and the crew who would sail the boat were also present and stood behind the boat owner. All the ceremonies are placed around the front end of Kalabiseang including the incense burner. The ceremony began with burning incense in the incense burner by punggawa (leader), almost simultaneously with burning incense, the boat owner put a white cloth on the head of the leader (like a veil). After the smoke of incense billowed, the Leader fumed the chisel and placed it perpendicular to the end of the kalabiseang line and then the leader specifically 'recited the mantra as follows:

"Dalle mambua' ilau. Sibuntulanko sicini. Namarannu pa'mai'nu. Mammakkang naha-nahannu." Meaning: fortune rises in the east. You meet view. Feeling happy. With a calm mind. 
After reading the mantra, then proceed with reading Basmalah and so on saying in your heart: a ... i ... $\mathrm{u}$ and right when you say the letter " $\mathrm{u}$ ", then the hammer is struck on the chisel several times. The pieces of chisel are taken by Leader and then divided into two, one part is given to the boat owner and another part is inserted into the Leader 's mouth to be "cooled" (cold symbol of peace of mind). The part taken by the boat owner is put into a bottle containing ivory coconut oil specially made by the boat owner's family. Ivory coconut fruit made from oil is taken from the tree facing east and located on the leaf midrib.

The end of the road that has been marked with a chisel, then cut using a saw without ever stopping to break up. If the saw stops before breaking, then it is magically seen that the boat will be broken off. Therefore the men who were assigned to cut the keel wood were selected from a number of crew members who were strong enough and experienced in cutting off the keel. After breaking at the two keel ends, a hole of a certain size is made as a symbol of female genitals. Then at the other end (or sotting) which will be connected with keel made pen (as a symbol of male genitals). Before the two ends of the beam (or sotting) are inserted into the keel hole, first put in: a little gold, steel, rice/rice crust, a little chicken droppings all of which are wrapped in cotton. After the cotton pack is inserted into the keel hole, then the two beams (or sotting) that have been made the pen are connected in full. In order not to concede water, the keel connection is inserted in a row.

On top of the two keeled ends that have been connected, by Leader smeared with the blood of the slaughtered chicken that had been prepared beforehand. The ceremony was declared complete after the Leader washed his hands and washed the face of the kettle water that had been provided. Furthermore the boat owner greeted the Leader while giving alms along with all the completeness of the ceremony, such as: chicken, cloth, banana, etc. All participants who attended the Annatta Kalabisenang ceremony were treated with prepared food such as diamonds, bananas and other cakes. Before the food is given to the participants of the ceremony, the Leader takes a little of each type of food and then wraps it with banana leaves and immerses it under the stretch of kalabiseang as a form of offering to the ruler of the place (bantilang).

\section{3) Tradition for Giving a Boat Center (Ammossi Lopi/Biseang)}

If the tradition of anna'bang kalabiseang is carried out in the forest area when starting logging/tree activities for the kalabiseang (lunas) beam, the annatta' kalabeseang tradition is carried out at the boat building as a sign that the boat construction activity is analogous to the starting point of the fetus then the ammossi tradition can be done when the boat is ready to be launched into 
the sea or declared to have been completed. The three traditions in making this boat from generation to generation have always been sacred where punggawa/panrita (expert boat makers) in each ceremony carrying out the tradition always communicate with the unseen world to obtain permission, protection, safety, and acquisition of sustenance from the boat they make.

The ammossi tradition is a activity of making possi (navel) as a sign of the birth of a baby (human) from the construction by a Punggawa (Leader) for several months (6-12 months) starting from meeting 1-3 rods/beam kalabiseang and with two sotting rods (front and the back of the boat) which is symbolized as a form of marriage between mother and father. If at the 'Kalabiseang' Annatta ceremony, the Punggawa acts as the leader in the marriage between the mother and father, then in the Ammossi ceremony 'biseang, the punggawa actually acts as a birth attendant or midwife. The ammossi tradition begins with the appassili (reject threats) ceremony and ends with the appakanre ballappati ceremony. A tradition that is intended to prepare yourself to avoid all possible disasters that can disrupt life activities.

Appassili is a ritual ceremony that is carried out at night before or together with the ammossi kalabiseang. Since the entry of the Islamic religion, this appassili ceremony has been colored with praising activities to the Prophet Muhammad, namely in the form of Barsanji. In this ceremony a number of completeness are prepared which are religiously meaningful such as: one water kettle taken from a particular spring (with the hope that the provision is never dry/disconnected), one bunch of leaves (consisting of sidingin leaves (cocor bebek: symbol of calm) sinrolo (similar vines with fast growth, hopes that the boat's success will increase rapidly), taha tinappasa (symbol of repelling evil creatures, hope the boat will avoid danger), taha siri (Siri': pride or shame if it doesn't work), panno-panno (a kind of full-meaning leaf, the hope is always full) tied together pimping, namely the elephant grass stems that are light and floating on the surface of the water, it is hoped that the boat will always have a good fortune or its fortune will always be on the surface or appear). Complete events are also prepared with traditional cakes such as: gogoso (collecting and wrapping rice from glutinous rice, hopefully the boat can collect wealth/property), kolengkung (layer cake, hope the boat gets sustenance in layers or stacked piles), onde-onde (cake made from rice, containing brown sugar and sprinkled with grated coconut, this cake when cooked floating, hopefully the boat will always be lifted), kaddo 'masinggkulu (ordinary rice cake wrapped in triangular bamboo leaves, singkulu means elbow/elbows, with the hope that the boat can ward off danger), songkolo (made of colorful rice and served on one tray, hope that the boat with a lake and all of its crew in the cruise remains compact or 
united), and utti labbu (long banana, hope so that the boat and its owner will long-lived).

After the Barsanji is hung up with great pleasure, one of the barsanji readers, especially the leader of the barsanji (specialist prayer reader or religion teacher) is called on duty specifically "read songkobala" (praying for danger repellent) in front of a small wask filled with sourced water from certain springs and one bundle of leaves mentioned above. The reading of this prayer is also done in a special or special way, after the prayer was read, the songkobala water was sprinkled around the boat by shaking it using the leaves of the leaves. Hopefully the boat can avoid danger from wherever it comes.

After the activity of the barsanji is declared complete, then as the culmination of the event is an ammossi biseang ceremony (symbol of cutting the umbilical cord to a newborn/created baby/boat). The cutting of the umbilical cord is based on the belief of punggawa (panrita biseang) that the boat is a child born of marriage between the mother (kalabiseang) and the father (sotting) at the start of the boat construction which is also carried out in the form of annatta ceremony 'kalabiseang.

In completing the ammossi biseang ceremony, completeness was prepared: 2 meter white cloth, a pair of adult chickens, ja'jakang (coconut, Ambon banana, brown sugar and diamond), a gold ring, one waskon, a set of pappisalingi (sarong, songkok, clothes), and censer. Before the ammossi biseang ceremony is carried out, all ceremonial skills are prepared around the middle of the boat's keel (kalabiseang) which is the place for the ceremony. When the ceremony will be held, the boat owner sits in a squatting position on the left side of the boat in full facing Punggawa (Panrita) who also sits in a squatting position on the right. The ceremony begins with burning incense by punggawa and the boat owner wears a white cloth on the Punggawa's head like a veil. Then the gold ring placed on a small plate is inserted into the mouth of the Punggawa, then the Punggawa fumigates the chisel from the puff of incense smoke while concentrating for a moment then reciting the mantra:

"Nabi Sulaiman tettong riolana lopi. Nabi Khaidir anjaga rilaleng risaliweng" Meaning: Prophet Sulaiman stood in front of the boat. The Prophet Khaidir was guarding inside and outside the boat.

Symbolically the mantra verses above show the surrender of the baby boat ("human beings") to the two prophets, namely the Prophet Solomon who was seen as the ruler of the earth and the Prophet Khaidir who was seen as the ruler of the ocean to be protected, guarded and saved. In their view, 
Prophet Khaidir is often referred to as the Prophet of Water (Source of Life or Carrier/Divorce from God).

After reading the mantra, the panrita regulates her breath, then says in her heart three letters that are considered sacred: $a \ldots$... i $\mathrm{u} \ldots$ and without breathing right at the pronunciation of the letter ... $u$... the chisel is hammered with a pedestal ax to make a rectangular hole in the middle of the wind. Sculptured fragments were taken several parts by the panrita and put into his mouth. The carved shape hole is then drilled in the right direction paid off, the crew leader is also ready to accommodate the drill cuttings under the boat hull using waskon. After the keel penetrates with the drill bit, the carved pieces in the panrita's mouth are sprayed into the drilled hole, repeated by adding water from the kettle provided, gargled, and so on again sprayed into the same drill hole. Next, the boat owner hands over a pair of chickens to the panrita, then the panrita cuts the hens/combs of the two chickens and the blood is dripped around the center of the boat, at the end of the face and back keel.

The end of the whole process of the ammossi biseang ceremony is marked by when the panrita washed her face just above the central hole. Drilling powder from the water that comes out of the center of the boat is accommodated in the waskon to be subsequently put together with pieces of sculpture at the annatta ceremony, 'he said in a bottle filled with ivory oil. Bottles containing a mixture of flakes and central hole powder, flakes at the time of annatta 'kalabiseang (splinters of pannatta' kalabiseang) and ivory oil are called lopi/biseang oil. This lopi/biseang mini bottle is then hung on the front of the inner boat. This lopi/biseang oil bottle can be taken at any time to be used as a bidder if the boat is facing danger in the sea, such as in the face of large waves which are considered to endanger the boat or hurricane which is expected to sink the boat.

The last session of the Kalabiseang Ammossi ceremony was the ballappati appakanre, which was led directly by the religion teacher. On the mat the teacher sara' sits on dragon beams near the center that was just created by the punggawa/panrita. Accompanied by the boat owner (husband and wife) on his right and skipper on his left, each facing the bow of the boat (sea). While burning the incense of the teacher sara 'praying, after praying, the wife of the boat owner handed over a newly hatched chicks to be bought and then chopped with a banana heart, mixed and stirred. The results of the teacher's sara chinca are then wrapped in banana leaves in a few packs, then placed at the center of the boat, on the keel front and rear joints and on the left and right canopy of the boat. Finally the boat owner's wife gave a package of suspicious kanre (rice complete with side dishes) which was 
placed on a banana leaf on the religion teacher', then the religion teacher divided it into two parts and wrapped it, the first package was asked to the captain to put it on the front keel and the second package is placed on the back of the keel connection. This appakanre ballappati ceremony is actually intended to energize unseenly at the focal point of the boat's strength so that it is expected to be strong in facing all possible dangers in the ocean.

\section{- Cultural Value and Religiosity}

The entire cultural pattern in making the traditional boat above (anna'bang kalabiseang, annatta 'kalabiseang, and ammossi biseang) is colored by magical views. It can be said that in making traditional boats, the Punggawa (Leader) of boat building (panrita lopi/biseang) is very upholding the occultation. If the traditional boat construction of Bugis Makassar is not based or refers to the view of occultation (religiosity), then the boat created from the hands of the Punggawa will have bad luck or not live long. The boat can be well constructed and completed on time, but if it is not faced with a magical view through the three traditions mentioned above, then the Punggawa cannot guarantee whether the boat will have good luck, sometimes it cannot even be launched into the sea. For Punggawa of boat makers, fortune, safety, and the strength of a boat that is seen as a living creature are very dependent on the magical power that is in the nature of the macrocosm. Because of that the boat (which is seen as a human being) which is part of the macrocosm (microcosm) must be able to maintain and maintain harmonization of relations even sometimes it still has to submit to the nature of the macrocosm. For example, at the Anna'bang Kalabiseang ceremony, before the tree is cut down, the Punggawa must first ask the tree: Are you willing to cut down for your boat? If the timber tree is paid off yet gives a symbolic answer to its approval, then the Punggawa will not cut it down, the timber tree is not like humans who can give direct approval, but because the Punggawa believes that the wood tree has an occult ruler, then the Punggawa must wait for an answer first, even though it's only symbolically. Likewise when seen from the verses of the mantra that are read by punggawa before cutting down a tree which means: "You are grown by the soil, nourished by rain, planted by Lukmanulhakim, Allah Taala who cut you down". These temples mean that even if the Punggawa has obtained approval from the tree/forest authorities, he still holds that in fact it is not the Punggawa in question who cuts it down but the God.

The same thing is observed in the annatta 'biseang ceremony, where the boat maker believes that the strength of the boat that rests on the keel beam can be obtained through sacralizing the keel (kalabiseang) with sotting, and the signaling is carried out in the form of a wedding ceremony the unseen world 
(between the mother (kalabiseang beam) and the father [sotting beam] under the leadership of the punggawa as the legitimate creation of the fetus or the attitude of the formation of a boat). The verses that were read courtesy of the annatted ceremony 'Kalabiseang also gave the meaning that as a newlywed it was necessary to give sustenance and the Punggawa also showed the existence of the sustenance and how to obtain it occultly in the verses which meant as follows: " Fortune rises in the east. You meet view. Feeling happy. With a calm mind. These temples mean that the existence of the person is always in the east where the sun rises, you should meet him, feeling happy and calm mind. Another meaning of the verses is that when you receive sustenance, you may be happy, but still with a calm mind.

Likewise, when listening to the Ammos Biseang ceremony, where the Punggawa views that the boat that has just been built must be seen as a newborn baby because it must be cut off the umbilical cord so that it is ready to enter a new life like a human. Because in infants, the umbilical cord cutting is generally done in a sacred manner, so the newly born boat must also be done sacred. In the Ammosi biseang ceremony, there are three forms of sacredness performed by punggawa, but since the entry of Islam, the boatman has been assisted by a group of barsanji readers and a religion teacher. The first sacred ceremony is at the appassili ceremony (the refusal ceremony) which begins with the reading of the barsanji and continues with the recitation of the songkobala (prayer invocation).

Along with the refusal prayer is also accompanied by a number of hopes for sustenance carried out in the language of symbolization (which consists of leaves and traditional cakes), the second sacred ceremony is the Ammossi biseang which is actually the culmination of the ceremony of the tradition of ammossi biseang (making umbilical cord). When observing the verses read by the Punggawa in the Ammossi Biseang ceremony which means: "Prophet Sulaiman stood in front of the boat. The Prophet Khaidir who guarded inside and outside the boat.", Can be obtained the meaning that the birth of the boat as" human "was seen as remaining in the protection or guarding of two great prophets in the view of Islam, namely Prophet Sulaiman who was understood as the ruler of the earth and the Prophet Khaidir understood as ruler of the ocean. Nevertheless the boat is still given the power of energy in the form of a lopi/biseang oil which is specifically made from flakes and powders as a result of making a boat center with ivory oil, which can then be used as a bidder if the boat turns out to be faced with danger in the sea, such as facing waves large or hurricane, etc. This energy supply is also increasingly strengthened through the appakanre ballappati ceremony where the sara teacher 'begins with prayer and continues with symbolic feeding to a number of boat power support points, such as the boat keel connection (face and rear) and boat canopy (left and right). 


\section{- Cultural Value and Religiosity in the Era of Industrialization}

The era of industrialization is characterized by modernization of equipment. Along with the modernization of shipping that diverts natural and human power to engine power as the main driving force in shipping, demanding that the boat be made bigger to be more economical in its function of transferring goods from one island to another. This demand brought considerable changes both in the procurement of raw materials (wood) and in the social structure of boat building. If previously the boat made only had a maximum tonnage of 150 tons, it can now reach 1500 - 2000 tons. This condition requires the birth of a financier (capitalist) whose role is to connect between prospective boat owners and boat makers, while looking for raw materials which are generally imported from outside the region (Kendari and Papua), especially prospective boat owners now generally want raw materials (wood) the types of wood used are selected, such as iron wood or the like.

The birth of the capitalist in making boats shifted the position of boat owners who had been in direct contact with boat makers. Likewise, the unavailability of local raw materials or the importation of all raw materials in making boats also simultaneously shifted the position of boat makers in taking straight wood (kalabiseang) in the forest. Thus the tradition of anna'bang kalabisenang is no longer carried out by the Punggawa of the boat maker. Along with the development of boat-making equipment which now mostly uses electric power both in sawing torches, as well as in smoothing wood, it also automatically shifts the view of boat makers from those who previously put the boat's power to magic power religious to the power of the boat based on work skills work) and the quality of raw materials without shifting the Punggawa's substantial knowledge in boat building. Knowledge in question is what researchers call assessment, a technical knowledge that is based on estimates (estimates), in making boats almost no exact or mathematical size is found, but almost all are determined on the basis of estimates. By knowing the full length (kalabiseang) on the basis of the size of the Punggawa's foot, then the Punggawa has been able to estimate (estimate) the weight of the boat. Say if the length of the stem reaches 17 sizes of the sole of the Punggawa, then the weight of the boat is estimated to reach $50-60$ tons $(17 \times 3=51$ : estimated at a minimum of $50-60$ tons $)$. The amount is played on the construction of the boat body, height or width so that the weight of the boat can be even greater.

Likewise the shift of boat owners in dealing directly with boat makers and the increasing demands of boat owners for the quality of boats physically also shifts the importance of sacredness in boat building. Even though the ceremony of Annaa Kalabiseang and Amossi Biseang are still being carried out, it is no longer too crowded with the era before industrialization, even in some cases it is only 
symbolically carried out with the aim of eliminating doubts. Thus the values of religiosity in the era of industrialization of boat building can certainly be weakened. Instead the appreciation for the quality of work seemed to be increasingly shown by boat makers both in the manufacture of traditional boats (Sailing Boat Three: Lambo, Seven Sailing Boats: Pinisi, etc.) and in the manufacture of modern boats (Sailboat Machines, Sailboats or Boats/Boats Machine). The quality of work is also shown from the use of raw materials where it is found that almost no wood is left or wasted in making boats, everything is used properly.

\section{Conclusions}

Based on the results and discussion of professionalism (cruelty), cultural patterns and cultural shifts in background values or underlying the making of traditional pinisi boats, the following conclusions can be formulated as follows:

a. Professionalism in making traditional pinisi boats is based on estimation, whose strength is built on the foundation of occult (occult/belief). The weight of a pinisi boat from the beginning can be estimated on the basis of the keel length (kalabiseang) which is measured using the punggawa (panrita) foot of the boat maker. Boats that are built from the hands of Punggawa are seen as living things (humans) and therefore can be built symbolically communication with the unseen world through a number of traditions ranging from logging in the forest to keel beams, keel cuts, to making umbilical cord. All of that is intended so that the boat can function optimally, bringing salvation and luck that continues continuously.

b. In line with the development of boat-making industrialization, the values of occultism that are expected to build boat strength experience a shift to appreciation for the quality of work. With the help of increasingly modern boat-making equipment, boat makers are increasingly showing their expertise in creating various boat models according to their customers' wishes. It's just that how strong the modern boat is created by industrialization in facing sea waves or more efficient and more environmentally friendly, there is no knowledge about it.

\section{Reference}

Creswell, (1998). Qualitative Inquiry and Research Design. Choosing Among Five Traditions. London: SAGE Publication, Inc.

Kaelan. (2005). Metode Penelitian Kualitatif Bidang Filsafat: Paradigma Bagi Pengembangan Penelitian Interdisipliner Bidang Filsafat, Budaya, Sosial, Semiotika, Sastra, Hukum dan Seni. Yogyakarta: Paradigma.

Kayam, Umar. (1986). Sawerigading dan Tiga Desa Pinisi. Jakarta: Tempo. 
Miles, M.B., dan A.M. Huberman. (1992). Analisis Data Kualitatif. Jakarta: Indonesia University Press.

Ramos, Alberto Guerrero. (1980). "Menuju Suatu Model Kemungkinan" dalam W.A. Belling dan G.O. Totten, Modernisasi: Masalah Model Pembangunan. Jakarta: YIIS.

Ritzer, George \& Douglas J. Goodman, (2004). Teori Sosiologi Modern. Jakarta: Kencana.

Ritzer, George, (2012). Teori Sosiologi: Dari Sosiologi Klasik Sampai Perkembangan Terakhir Postmodern. Yogyakarta: Pustaka Pelajar.

Saenong, Muhammad Arief. (2013). Pinisi: Panduan Teknologi dan Budaya. Yogyakarta: Penerbit Ombak.

Sugiyono, (2007). Memahami Penelitian Kualitatif. Bandung: Alfabeta.

Weber, Max. (1958). The Protestant Ethic and the Spirit of Capitalism. New York: Charles Scribner's Sons. IRCiSod. (2006). Studi Komprehensif Sosiologi Kebudayaan. Yogyakarta : 